\title{
Anti-Corruption Education Model in Islamic Universities
}

\author{
Firman ${ }^{1}$, Nurdin K. ${ }^{\text {, }}$ Arifuddin ${ }^{3}$, Mirnawati 4, Dodi Ilham 5 , Abdul Rahim \\ Karim6
}

DOI: $10.35445 /$ alishlah.v13i3.843

\begin{tabular}{l}
\hline Article Info \\
\hline Keywords: \\
Anti-corruption \\
education; \\
Corruption in Indonesia; \\
Islamic universities
\end{tabular}

Kata kunci:

Pendidikan anti korupsi; Korupsi di Indonesia; Universitas Islam

\begin{abstract}
This study aims to describe the forms of corruption from a religious perspective and efforts to cultivate anti-corruption values in Islamic religious colleges. This research is a literature review by examining various semester learning plans, syllabus, textbooks, reference books, and journals relevant to the research topic. Semester lesson plans, syllabus, textbooks, reference books that were studied were sourced from the learning curriculum at the State Islamic Institute of Palopo and State Islamic Institute of Bone. The author's steps are 1) topic selection, 2) topic exploration, 3) affirmation of the focus of the study, 4) literature review and classification. The instrument used consisted of two items: collecting symbolic data and making data cards. Based on the study results, it was found that the involvement of Islamic religious universities in efforts to prevent corruption is essential to shape Indonesian citizens' character, character, attitudes, and behaviour. Anti-corruption education in Islamic religious colleges aims to provide students with sufficient knowledge about the ins and outs of corruption and its eradication and instil anti-corruption values. The anti-corruption education model at PTKI (religious colleges) can be carried out with the following models: 1 ) anti-corruption education is integrated into courses; 2) anti-corruption education is integrated into student activities; and 3) cultural habituation and anticorruption character on-campus residents.
\end{abstract}

\begin{abstract}
Abstrak
Penelitian ini bertujuan untuk mendeskripsikan bentuk-bentuk korupsi dari perspektif agama dan upaya penanaman nilai-nilai antikorupsi di perguruan tinggi agama Islam. Penelitian ini merupakan studi literatur dengan menelaah berbagai RPP, silabus, buku teks, buku referensi, dan jurnal yang relevan dengan topik penelitian. RPP semester, silabus, buku teks, buku referensi yang dipelajari bersumber dari kurikulum pembelajaran di Institut Agama Islam Negeri Palopo dan Institut Agama Islam Negeri Bone. Langkah-langkah penulis adalah 1) pemilihan topik, 2) eksplorasi topik, 3) penegasan fokus penelitian, 4) tinjauan pustaka dan klasifikasi. Instrumen yang digunakan terdiri dari dua item yaitu pengumpulan data simbolik dan pembuatan kartu data. Berdasarkan hasil penelitian ditemukan bahwa keterlibatan perguruan tinggi agama Islam dalam
\end{abstract}

\footnotetext{
${ }^{1}$ IAIN Palopo, Palopo, Indonesia

Email: firman_999@iainpalopo.ac.id

2 IAIN Palopo, Palopo, Indonesia

Email: nurdin_k@iainpalopo.ac.id

3 IAIN Palopo, Palopo, Indonesia

Email: arifuddin_arif@iainpalopo.ac.id

4 IAIN Palopo, Palopo, Indonesia

Email: mirnawati@iainpalopo.ac.id

5 IAIN Palopo, Palopo, Indonesia

Email: dodi@iainpalopo.ac.id

${ }^{6}$ IAIN Palopo, Palopo, Indonesia

Email: abdulrahimkarim@iainpalopo.ac.id
}

Vol.13 (3) December 2021.

Received: July 24, 2021; Received in revised form: December 5, 2021; Accepted: December 12, 2021; Available online: December $23,2021$.

This is an open-access article under a Creative Commons Attribution-NonCommercial-ShareAlike 4.0 International License 
upaya pencegahan korupsi sangat penting untuk membentuk karakter, karakter, sikap, dan perilaku warga negara Indonesia. Pendidikan antikorupsi di perguruan tinggi agama Islam bertujuan untuk membekali mahasiswa dengan pengetahuan yang cukup tentang seluk beluk korupsi dan pemberantasannya serta menanamkan nilai-nilai antikorupsi. Model pendidikan antikorupsi di PTKI dapat dilakukan dengan model sebagai berikut: 1) pendidikan antikorupsi diintegrasikan ke dalam mata kuliah; 2) pendidikan anti korupsi diintegrasikan ke dalam kegiatan kemahasiswaan; dan 3) pembiasaan budaya dan karakter antikorupsi warga kampus.

\section{INTRODUCTION}

Indonesia was independent on August 17, 1945; independence does not mean being free from various problems. One of the goals to be achieved by the State of Indonesia is following what is stated in the preamble to the 1945 Constitution of the Republic of Indonesia, namely to protect the entire Indonesian nation and the entire homeland of Indonesia and to promote public welfare, educate the nation's life, and participate in carrying out world order based on independence, eternal peace, and social justice (Gardiner, 2017). In realizing this goal, the Indonesian state has experienced various problems to have not been fully achieved. One of the problems faced is corruption. Contrary corruption, for causing damage to various aspects of the life of the Indonesian people (Henderson \& Kuncoro, 2011). Some so many people are hurt and become victims of corrupt practices. Corruption occurs in central government officials, and many local officials are affected by corruption cases.

In essence, corruption is a "social parasite" that destroys government structure and becomes the main obstacle to the running of government and development in general. Corruption is complicated and almost impossible to eradicate (Doig \& Riley, 1998). Because it is tough to provide actual evidence; besides, it is tough to detect it with a solid legal basis. However, access to acts of corruption is a latent danger that must be watched out for both by the government and by the community itself.

The book s1 issued by the Corruption Eradication Commission (KPK) in 2006 mentions various forms of corruption, namely: state financial losses, bribery, embezzlement in office, extortion, fraudulent acts, conflicts of interest in procurement, and gratuities (Ministry of Education and Culture RI, 2006; 25-27). The Corruption Eradication Commission (KPK) defines corruption as an abuse of authority, clearly explained in 13 Law no. 31 of 1999. UU no. 20 of 2001. Based on the law, corruption crimes can generally be grouped into seven types: 1 . State losses; 2. Bribes; 3 . Embezzlement in office; 4. The act of extortion; 5. Cheating; 6 . Conflict of interest in procurement; and 7. Gratification. (Drafting Team, 2006; 4-5).

Law enforcement officers can solve corruption, but the world of education is also expected to prevent corruption from an early age. Education is a forum for forming the nation's next generation that effectively prevents corruption. Eradication of corruption is not enough to punish and give lectures or anti-corruption seminars. The corruption in Indonesia needs to be found out from the root of the problem. Providing sufficient anti-corruption education will protect future generations from rampant corruption.

The People's Consultative Assemblymember, Hidayat Nur Wahid, stated that education needs to be elaborated and internalized with anti-corruption values early. Anti-corruption education provided in schools/campuses is expected to save the younger generation from becoming the successors to the corrupt actions of the previous generation. Still, it is just that providing anti-corruption education is not easy. Because even the emergence of the phenomenon of corrupt practices also started from the world of education, which tends never to provide mainstream or paradigm of honest behaviour in saying and doing, including schools in this country. For example, teachers/lecturers explain idealistic things in giving lessons, saving for rich bases, but in reality, many teachers/lecturers are corrupt, such as corruption of the time, corruption of the subject matter given, corruption in the form of absence teaching class permission. The things done can also trigger worse corrupt practices in education (Frimayanti, 2017: 91-92). 
The above facts lead to the need for the involvement of education in efforts to prevent corruption. The path of education is essential to shape Indonesian citizens' character, character, attitudes, and behaviour. Formal education involvement campus to prevent corruption is not new; it has a strategic position. In line with the view of progressivism, schools are agents of social change whose job is to introduce new values (Pol. M. Hlouskova, et al., 2005; Hakim, L; 2012)

Herman Suparno explained that the quality of education largely determines the progress of a nation. Therefore, education as a means to educate the nation's life has a very strategic role. Furthermore, education contributes to developing quality human resources (HR), with indicators of expert qualification, skill, creativity, innovation, and positive attitude (Herman Suparno, 2008: xxiii).

One of the considered effective institutions in overcoming corruption is the Islamic religious college (PTKI). Islamic Higher Education is one of the means for Muslims to continue to improve the community's quality of life through the development of science and religious values. Islamic Higher Education is an educational institution that emphasizes the moral aspect; its scientific development must be dynamic and sensitive to changes in the patterns and behavior of people's lives (Siful Arifin, 2015: 10).

Islamic Higher Education is a university in Indonesia whose management is under the Ministry of Religion. Technically academically, the development of State Islamic Universities is carried out by the Ministry of National Education, while functionally, it is carried out by the Ministry of Religion. Currently, there are three types of state Islamic Universities, namely: State Islamic University (UIN), State Islamic Institute (IAIN), and State Islamic College (STAIN) (Siful Arifin, 2015: 10).

Efforts to prevent corruption in society can first be made by preventing mental corruption in Indonesian children through education. It is realized that eradicating corruption cannot be separated from the preventive movement, preventing mental corruption in its generation. Considering that prevention efforts can not only be done in one generation but the next two or three generations.

Anti-corruption education in Islamic religious colleges aims to provide students with sufficient knowledge about the ins and outs of corruption and its eradication and instil anti-corruption values. The long-term goal is to foster an anti-corruption culture among students and encourage students to eradicate corruption in Indonesia actively.

In the context of the anti-corruption movement, students are also expected to appear in front as a driving force. Students are supported by their essential competencies: intelligence, critical thinking skills, and the courage to state the truth. With the competencies possessed, students are expected to become agents of change, voice the people's interests, criticize corruptive policies, and become watchdogs of state institutions and law enforcement. The critical role of these students cannot be separated from the characteristics they have, namely: intellect, youth, and idealism. With high intellectual ability, youthful enthusiasm, and pure idealism, it has been proven that students have always played an essential role in the history of this nation's journey. This nation's journey has proven that students play a vital role as change agents in several significant events. Evans (2009) explained that corruption prevention could be done by socializing anti-corruption values. This prevention process is critical in overcoming corruption because eradicating corruption will be more optimal with this prevention process.

Anti-corruption education is a lifelong education that must be instilled in children as soon as possible. Human resources are the most important factor to consider when it comes to national development. One of the prerequisites for effectively developing Indonesian human resources is cultivating character (Nur et al., 2021). The campus serves as a printing press for the nation's next generation. Anti-corruption education is expected to be a concern on campuses. With this background, the author was motivated to parse this document by attempting to take photographs while simultaneously offering several alternative models of anti-corruption education management in Islamic religious colleges that take into account the current situation and conditions. 


\section{METHODS}

This research is a literature review by examining various semester learning plans, syllabus, textbooks, reference books, and journals relevant to the research topic. Semester lesson plans, syllabus, textbooks, reference books that were studied were sourced from the learning curriculum at the State Islamic Institute of Palopo and State Islamic Institute of Bone. The steps that the author takes are: 1) selecting the topic of anti-corruption education studies on the sources mentioned above; 2) exploring the topic of anti-corruption education studies; 3) emphasizing the focus of the study on anti-corruption education, especially on aspects of institutional management and learning; 4) review and classify the anti-corruption education literature. The instrument in this study consisted of two items: collecting symbolic data through academic texts that had not been analyzed so far and making data cards as notes to clarify the findings in the text.

\section{FINDINGS AND DISCUSSION}

"Corruption" is defined in the Big Indonesian Dictionary (Balai Pustaka, 2001: 597) as the misappropriation or misuse of state funds for personal gain or for the benefit of other people. "Corruptius," or corruptio, is the Latin word for "corrupt." "Corruptus" is a Latin word that means "to abuse or deviate." As a term of endearment in Indonesian, "corruption" refers to the use of power for personal gain, such as embezzlement or accepting bribes (Dictionary, 2008; 756). "Corruptie" or "Corruptus," according to Nurdjana (2010, p. 14), is the Latin word for corruption. In Latin, the word "corrumpore" means "corrupted" (an old Latin word). English, French, and the Dutch all have words derived from the Latin word corruptie, which means "corrupt" in Latin (korruptie). Corruption (from the Latin corruptio, meaning bribery, and corrumpore, meaning damage) is a sign that state agencies misuse corruption, forgery, and other irregularities to their advantage.

Crime, corruption, bribery, immorality and dishonesty are all examples of corruption. Embezzlement, accepting bribes, and other wrongdoing. Third, actions that lead to bad conditions or immorality; bribery and other dishonest practices; Words or phrases that have been changed or replaced incorrectly; corrupted influences. (Mulyadi, 2007: 78). Corruption is often followed by collusion and nepotism, known by the Indonesian acronym as "KKN" (Corruption, Collusion, and Nepotism). KKN now becomes a world problem that must be eradicated and made into the government's plan to be addressed seriously and urgently, as part of the program to restore the trust of the people and the international community to increase the country's economic growth. Transparency International defines corruption as an act of abusing public power and trust for personal gain (Pope, 2003; 6)

Kartono (2013; 90) mentions corruption as behaviour that uses authority and position to make personal gains to the detriment of the public and state interests. In essence, corruption is a "social parasite" that destroys government structure and becomes the main obstacle to the running of government and development in general. Corruption is complicated and almost impossible to eradicate because it is tough to provide actual evidence. Besides, it is tough to detect it with a solid legal basis. However, corruption is a latent danger that must be watched out for by both the government and the community.

Anti-corruption can be interpreted as an attitude of disapproval, dislike, and displeasure towards acts of corruption, which can prevent and eliminate opportunities for the development of corruption. Preventing is an effort to increase individual awareness, not commit corruption, and save money and state assets. Thus, anti-corruption education is a conscious effort to understand and prevent corruption through formal education in schools, informal education in the family environment, and non-formal education in the community (Development Team, 2013; 6). While anti-corruption education instils an attitude of refusing to be involved in corruption and fighting corruption in society, in this context, anti- 
corruption education raises awareness and praxis movement among individuals, students, or community members not to tolerate acts of corruption in any form (Agus Supandi, 2015: 34).

Anti-corruption education is abstract, not through logic alone. This education requires a stage of reasoning, internalization of values and morals so that the subjects are designed to emphasize the cognitive aspect and the affective and psychomotor aspects (Yusrianto Kadir, 2018: 35). AntiCorruption Education is a conscious effort to understand and prevent corruption through formal education at school or on campus, informal education in the family environment, and non-formal education in the community. Anti-corruption education does not stop introducing anti-corruption values but continues to understand, appreciate, and practice anti-corruption values into daily life habits (Agus Supandi, 2015: 32).

\section{Forms of Corruption}

Various forms of corruption taken from The Pocket Book issued by the Corruption Eradication Commission (KPK) in 2006, namely: Loss of State Finances, Bribery, Embezzlement in Position, Extortion, Cheating, Conflicts of Interest in Procurement, and Gratification (Ministry of Education and Culture RI, 2006; 25- 27). The Corruption Eradication Commission (KPK) defines corruption as an abuse of authority, clearly explained in 13 Law no. 31 of 1999. UU no. 20 of 2001. Based on the Law, corruption crimes can generally be grouped into seven types: 1. State losses; 2. Bribes; 3. Embezzlement in office; 4. The act of extortion; 5. Cheating; 6. Conflict of interest in procurement; and 7. Gratification (Preparation Team, 2006; 4-5). According to Agus Wibowo (2013: 28-30), he describes the types of corruption are as follows:

a. Corruption related to state financial losses, such as against the law to enrich oneself and harm the state's finances;

b. corruption related to bribery, such as bribing civil servants, judges, advocates, and more;

c. corruption related to embezzlement in office, such as civil servants embezzling money, and destroying evidence, and more;

d. Corruption related to acts of extortion, such as extorting civil servants and forcing others to give something in return;

e. Corruption related to fraudulent acts, such as contractors cheating, civil servants taking state land to the detriment of others;

f. Corruption related to conflicts of interest in procurement, such as civil servants participating in the procurement

The various forms of corruption described above, the forerunner of corruption is due to the selfish nature of humans. Everyone tends to be egocentric, self-absorbed. Under these conditions, the tendency for corruption will be even more significant, along with the increasing consumptive needs and the increasing importance of personal welfare compared to public welfare (Penkauskienè, 2006).

\section{Corruption in the Perspective of Islam}

In Islam, The term corruption is called ghulul (embezzlement), which means embezzlement or cheating on the spoils of war, rishwah (bribery) this term is taken from the hadith of the Prophet in (alShaukani: 172) according to Ibrahim Anis is something given to justify the vanity or blame the right (Abdul Gaffar, 2016: 199). In addition, corruption is also called ghasab (taking the rights/wealth of others forcibly). This term is taken from (Surah al-Nisa: 29 and QS. al-Baqarah: 188), which is terminology defined as an attempt to control the rights of others in a hostile/open manner, khiyanah (breach of trust) this term is taken from (QS. Al-Anfal: 27) which means taking property secretly and showing good behaviour towards the owner of his property, sariqah (theft) which means taking goods/wealth secretly from the place of storage. Which is usually used to store goods or assets, and hirabah (robbery), according to al-Shafi'i, namely attacks by carrying weapons to a community of people so that the perpetrators seize their assets in the open openly (Abdul Gaffar, 2016: 199).

Hafidhuddin, in Semma (2008; 33), explains that according to the Islamic view, corruption is an act fasādor actions that destroy the order of life, and the perpetrators are categorized as committing jināyah qubrā (major sin). In the broader context of Islamic teachings, corruption is an act that is contrary to the principles of justice (al-'adālah), accountability (al-amānah), and responsibility. The Qur'an has explained how humans should behave on this earth, how they carry out their mandate and 
do justice to Allah SWT. In QS. an-Nisa verse 58, which essentially encourages people not to abuse or distort the mandate and the command to do justice. It is so essential to carry out the mandate and does justice.

Islam interprets corruption as contrary to social, economic, and ecological justice (Iqbal, 2002: 133). Thus, corruption in the perspective of the Qur'an includes all human actions that interfere with the lives of other individuals, destroy social harmony, and endanger the surrounding environment. It is explained in QS. al-Rum, verse 41, means "Corruption has appeared on land and in the sea due to human actions...”. It implies that Islam views corruption as a moral and ethical problem requiring firm intention and determination to avoid corruption and fortify oneself from corruptive things.

In anti-corruption education, trustworthiness and fair dealing are closely related. One example of a mandate is to be fair. If humans have denied justice and do not act reasonably in life in this world, it will cause other humans to be persecuted due to the injustice of some of these humans. The oppression of some people by others, causing suffering, misery for others, and excess or spaciousness (both wealth, position, and opportunities) for others by their unfair actions and violating the rights of others against others (who commit crimes). Unfair or unreasonable).

Islamic religious values clearly state that Islam explicitly publishes the concepts of justice, honesty, trustworthiness and condemns corruption, collusion, and nepotism. As the Word of God: "And do not let some of you eat the wealth of others among you in a wrong way and (do not) take the property to the judge, so that you may eat a part of the property of others by sinning, even though you are knowing.(Surah Al-Baqarah verse 188). This verse explains that Islamic religious values lead to sharing. Still, the root cause of the problem is the internalization of Islamic values to its adherents, which is very much needed. Hence, lecturers' task is to seek the internalization of these values. A learning model practised by Rasulullah SAW, as quoted by Arifuddin (2019: 39) that learning model practised by the Prophet aims to form productive humans and can contribute to the birth of a scientific civilization that does not stop at the level of knowledge but can be realized in everyday life. The Prophet always made goodness the main plan and mission in every person's actions.

Ahmadi, as quoted by Frimayanti (2017; 87), mentions Islam as a perfect religion has provided a clear footing on the purpose and nature of education, namely empowering the potential of human nature that leads to the values of truth and virtue so that he can place himself as a servant. Therefore, the definition of Islamic education is "all efforts to develop human nature and human resources towards the formation of a complete human being by Islamic norms.”

\section{Anti-Corruption Education Goals and Values}

A goal to be achieved by education is essentially an embodiment of the ideal values formed in the desired human person. Moreover, these ideal values influence and colour the pattern of human personality to be symptomatic in their outward behaviour. Therefore, in carrying out anti-corruption education, it is hoped that the aspired goal will be achieved, namely the existence of humans who are responsive and care about the problems that occur in the surrounding environment. This goal can arouse enthusiasm for anti-corruption.

Muhaimin (2009: 182) says that the failure of education is due to the learning process which only prioritizes the cognitive aspect of growing awareness of Islamic values and ignores the affective aspects, namely the determination to do charity. Agus Wibowo (2013: 35) adds that education should be a normative effort that refers to noble values that are part of the life of the nation, then education is carried out through the role of education transfer both in terms of cognitive, attitude (affective), and skills ( psychomotor). Education will make humans more mature intellectually, morally, and socially. In addition, it must also be able to transform values as the basis (foundation), mainly Islamic values.

In the context of anti-corruption education, the most important thing to emphasize is that the purpose of value education is not only rhetorical skills about values or an ideology. However, it is far more critical to use knowledge and adherence to Islamic values to foster the ability to guide the nation to a new way of life (way of life) according to the existing reality. Therefore, value education does not 
stop introducing values but must continue to understand, appreciate, and practice values. Only with a cycle of values education can be expected to bring the nation towards a better chance.

Anti-corruption education combines values education and character education $-\mathrm{a}$ character built on honesty, integrity, and nobility. Anti-corruption education for children needs to be instilled early because they can also act negatively. For example, they take other people's belongings without notifying the owner. Psychologically, this trait is owned by every child. Only its realization requires certain conditions. If children are not appropriately educated early, negative traits will appear. Academically and psychologically, this is justified, but it will be fatal (Frimayanti, 2017: 93).

According to Muchlas Samani (2011: 9) explains that the values of National Character Education are:

\begin{tabular}{llll}
\hline 1 & Religious & 10 & Spirit of nationality \\
\hline 2 & Honest & 11 & Love the Motherland \\
\hline 3 & Tolerance & 12 & Appreciating Achievements \\
\hline 4 & Discipline & 13 & Friendly / Communicative \\
\hline 5 & Hard work & 14 & Love peace \\
\hline 6 & Creative & 15 & Like to read \\
\hline 7 & Independent & 16 & Care for the environment \\
\hline 8 & Democratic & 17 & Social care \\
\hline 9 & Curiosity & 18 & Responsible \\
\hline
\end{tabular}

The Corruption Eradication Commission (KPK) outlines that nine fundamental values need to be instilled and strengthened by implementing anti-corruption education in schools and universities: honesty, fairness, courage, simple life, responsibility, discipline, hard work, and hard work, frugality, and independence. Maria, 2012: 295).

Presidential Instruction of the Republic of Indonesia No.1 of 2013 Tahunrelated to the strategy of preventing and eradicating corruption, it is explained that efforts to prevent and eradicate corruption can be carried out by a. prevention; b. law enforcement; c. legislation; $d$. international cooperation and rescue of assets resulting from corruption; e. anti-corruption education and culture; and f. reporting mechanism. If this is not addressed, then according to Alatas SH in (Nugraheni, 2016; 14-27) suggests six harmful effects that can be caused by corruption, namely: (1) the emergence of forms of injustice, (2) causing inefficiency, (3) fertilizing types of corruption. Other crimes, (4) weakening the spirit of the bureaucratic apparatus and those who are victims, (5) reducing the state's ability to provide public services, and (6) increasing the cost of services.

In general, the objectives of anti-corruption education are: (1) the formation of knowledge and understanding of the forms of corruption, (2) changing perceptions and attitudes towards corruption (3) the formation of new skills and skills to fight corruption. Anti-corruption education is generally considered cultural correction education that introduces new ways of thinking and values to students. Anti-corruption education must integrate three domains, namely the domain of knowledge (cognitive), attitudes and behaviour (affective), and skills (psychomotor) (Agus Supandi, 2015: 32).

According to Haryono Umar, as quoted by Agus Wibowo (2013: 38), the purpose of anticorruption education is to build exemplary character, not to commit corruption from an early age. On the other hand, children/students can also become promoters of eradicating corruption. So, the younger generation needs to be instilled in an anti-corruption mentality and good values early. Currently, character education has been implemented at various levels of education. Substantively, education in Indonesia, as stated in Law no. 20 of 2003, is character education. Moreover, it is hoped to strengthen character education with anti-corruption education further if implemented in tandem and synergy. So anti-corruption education is part of character education and education in general. 
Thus, anti-corruption education aims to create awareness among students about the dangers of corruption and then rise against it. Inspire the public to be active against corruption and avoid internalizing a permissive attitude towards corrupt acts. Anti-corruption education is also helpful in promoting the values of national character education.

\section{Anti-Corruption Management Model at PTKI}

The problem of corruption that is being experienced now is studied historically; corruption has existed since humans existed. Wijayanto (2009) stated that judging from the history of corruption, it has existed simultaneously with the birth of human civilization; even corruption is believed to have arisen simultaneously as the human age itself. We can see this from human nature that wants to dominate each other, giving rise to competition and a sense of wanting to beat. This condition makes people forget the rights and obligations that should be held so that corruption appears. Therefore, corruption is not a new phenomenon but a problem that has existed for a long time and is difficult to eradicate. Moreover, as discussed above, corruption has entered into every aspect of the life of the Indonesian nation. As a result, the high number of practices, the public also seems to have considered the problem of corruption typical so that the perpetrators of corruption become more flexible to practice freely.

One thing is no less important in eradicating corruption, namely, preventing corruption. Therefore, prevention is an integral part of the corruption eradication program. Therefore, the prevention of corruption must be carried out at every level of education. Why is that? First, corruption can only be removed from our lives gradually. Second, education should be an intersection between character education and civic education to eradicate corruption. Third, education to reduce corruption must be in value education (Islam), namely education to encourage each generation to reconstruct the inherited value system (Frimayanti, 2017: 91-92).

Pradiptyo (2009) states that prevention and preventive measures will be more helpful in overcoming corruption than by taking high legal sanctions. It shows that corruption prevention must be appropriately optimized in eradicating corruption in Indonesia. In PTKI (religious universities), the anti-corruption education model can be carried out with the following models, namely:

\section{Anti-Corruption Education is integrated into the course}

The anti-corruption education model is integrated with all courses to assume that all anticorruption education lecturers are without exception. All courses are assumed to have a moral mission to build anti-corruption students. Anti-corruption values that will be instilled are selected and included in the subject matter. Lecturers include anti-corruption values that can be instilled through several points or sub-topics related to values life. Understanding the value of anti-corruption in students is informative-cognitive and applied to every subject.

The anti-corruption education model that is applied is a collective responsibility for lecturers. Until the modelling-corruption education integrated with courses requires readiness, insight, morals, and exemplary teachers, on the other hand, this model also demands the creativity and courage of the teachers in compiling and developing the syllabus and lecture plans (Siful Arifin, 2015: 13).

The advantage of this model is that all lecturers are responsible for teaching anti-corruption values corruption against students. The weakness of this model is that the understanding and perception of anti-corruption values that will be instilled must be clear and the same for all lecturers.

According to Nurul Yaqin (2015: 278-279), anti-corruption values and behaviors are integrated into subjects/courses can be identified as follows:

\begin{tabular}{ccc}
\hline No & Anti-corruption values and behaviour & Characteristic features \\
\hline 1 & Recognize corrupt behaviour that must be avoided & $\begin{array}{c}\text { a. Recognize the characteristics of corrupt } \\
\text { behaviour that need to be avoided. } \\
\text { b. Accustomed to doing tasks on time } \\
\end{array}$ \\
& $\begin{array}{c}\text { c. Show examples of known cases of corrupt } \\
\text { behaviour at home, at madrasas/campus, } \\
\text { and in the community. }\end{array}$ \\
& $\begin{array}{c}\text { d. Show examples of cases of behaviour that } \\
\text { do not contain elements of corruption }\end{array}$ \\
\hline
\end{tabular}




\begin{tabular}{|c|c|c|}
\hline & & $\begin{array}{l}\text { that have been carried out by } \\
\text { students/students }\end{array}$ \\
\hline 2 & $\begin{array}{l}\text { Be honest, disciplined, responsible, and fair in daily } \\
\text { life. }\end{array}$ & $\begin{array}{l}\text { a. Dare to say something by the actual } \\
\text { situation. } \\
\text { b. Get used to doing things promptly. } \\
\text { c. Accustomed to carrying out tasks } \\
\text { promptly. } \\
\text { d. Accustomed to being impartial to anyone } \\
\text { in carrying out an action }\end{array}$ \\
\hline 3 & Only accept a gift according to what is rightfully his & $\begin{array}{l}\text { a. Refuse a gift that is not by its rights. } \\
\text { b. Do not want to take something that does } \\
\text { not belong to us. }\end{array}$ \\
\hline 4 & Respect and fulfil the rights of others & $\begin{array}{l}\text { a. Giving something to someone else } \\
\text { according to their rights. } \\
\text { b. Never give to others something that is not } \\
\text { their right. }\end{array}$ \\
\hline 5 & $\begin{array}{l}\text { Able to analyze the causes and consequences of } \\
\text { corrupt behaviour in the life of society and the state }\end{array}$ & $\begin{array}{l}\text { a. Able to identify the causes that encourage } \\
\text { the emergence of corrupt behaviour in the } \\
\text { life of society and the state. } \\
\text { b. Able to identify the consequences of } \\
\text { corrupt behaviour in the life of society } \\
\text { and the state. } \\
\text { c. Able to state the reasons for the need to } \\
\text { avoid corrupt behaviour in the life of } \\
\text { society and the state }\end{array}$ \\
\hline 6 & Have pride in anti-corruption behaviour & $\begin{array}{l}\text { a. Proud of anti-corruption behaviour. } \\
\text { b. Anti-corruption behaviour. }\end{array}$ \\
\hline 7 & $\begin{array}{l}\text { Cultivating anti-corruption behaviour in the family } \\
\text { and community }\end{array}$ & $\begin{array}{l}\text { a. Spreading ideas and desires to avoid } \\
\text { corrupt behaviour } \\
\text { b. Demonstrate a commitment to rejecting } \\
\text { corrupt behaviour. } \\
\text { c. Be a role model for anti-corruption } \\
\text { behaviour }\end{array}$ \\
\hline
\end{tabular}

Universally, several values can shape character students better: honesty, caring and respect for others, hard work, responsibility, simplicity, justice, discipline, cooperation, courage, and fighting power/tenacity. (Setiawan, 2012) By integrating these values into life/learning activities, it is hoped that students will develop into better individuals and ultimately be anti-corrupt.

\section{Anti-corruption education is integrated into student activities}

It was planting anti. Value corruption can be instilled through activities outside of learning, such as extracurricular/student activities. In principle, all student activities intrinsically contain different anti-corruption values and behaviour levels. However, if it is not developed intentionally and planned, it will not grow and develop effectively. The student activities in question are student activities that have existed and been implemented or those that will be held and implemented, both routinely and incidentally.

The anti-corruption education model integrated with student activities can be pursued in two ways: an extracurricular activity managed by the campus with a person in charge of extracurricular activities held by students independently without campus involvement. For example, seminars, workshops, or other activities organized by intra-campus organizations or extra-campus organizations involve students. In this extracurricular activity, students are expected to raise themes related to corruption. In addition, technically, students are expected to make accountability reports related to the implementation of the event to related parties in a transparent and accountable manner. Second, through partnerships with other institutions concerned about preventing anti-corruption behaviour. Students can do this activity through formal and non-formal events. For example, they hold intense scientific discussions with institutions engaged and concerned in eradicating corruption (Siful Arifin, 2015: 13). 
According to Nurul Yaqin (2015: 281), anti-corruption values and behaviours that are instilled through the development of student activities can be identified as follows:

a. Demonstrate an objective attitude oriented to personality qualities and professional abilities in selecting prospective administrators or leaders.

b. Carry out tasks or work by the functions and responsibilities full of sincerity and a sense of devotion.

c. Demonstrate an open attitude in planning and carrying out joint activities.

d. Demonstrate an open attitude in managing the financial budget of activities.

e. Have high motivation and creativity in expressing anti-corruption ideas.

f. Have strong courage to participate in eradicating corruption.

g. Have a solid and broad insight and mindset regarding anti-corruption behaviour.

h. Demonstrate deep appreciation and appreciation of anti-corruption behaviour.

i. Have various commendable attitudes that can avoid corrupt behaviour.

j. Have strong feelings and impressions to avoid corrupt behaviour.

\section{Cultural habituation and anti-corruption character on-campus residents}

The inculcation of anti-corruption values can also be instilled through cultural habituation and anti-corruption character for all activities of campus residents. The campus residents in question are lecturers, staff, students, security units, and more. Who are active on campus. Cultivating anticorruption values can be instilled through civilizing in all activities and university atmosphere. Cultivation will lead to habituation. Anti-corruption culture on campus can be grown by conducting civilizing and habituation activities. This model takes place during lecture hours and outside lecture hours, including all campus activities. Such as transparent financial management, accountable and professional campus management, and campus community behaviour (Lecturers, stakeholders, and more) are disciplined and responsible (Siful Arifin, 2015: 14). Anti-corruption values and behaviours that are instilled through habituation of behaviour can be identified as follows:

a. Have a solid anti-corruption spirit and commitment.

b. Behave openly, be responsible and uphold the public interest.

c. Be honest with ourselves and others in conducting transactions.

d. Behave only to accept something rightfully his or not or take something, not his. Nurul Yaqin (2015: 283)

This habituation will give birth to campus residents a strong culture and character. Anticorruption culture on campus can be grown by conducting civilizing and habituation activities. Habituation is an educational tool. For students, habituation is very important because it is through habituation that activity will eventually become the property of students in the future. Good habituation will form a human figure with a good personality as well. Conversely, bad habits will also form a human figure with a lousy personality.

\section{CONCLUSION}

Anti-corruption education in Islamic religious colleges aims to provide students with sufficient knowledge about the ins and outs of corruption and its eradication and instil anti-corruption values. The long-term goal is to foster an anti-corruption culture among students and encourage students to eradicate corruption in Indonesia actively. The anti-corruption education model at PTKI (religious colleges) can be carried out with the following models: 1) anti-corruption education integrated into courses; 2) anti-corruption education is integrated into student activities; and 3) cultural habituation and anti-corruption character among campus residents 


\section{REFERENCES}

Arifin, S. (2018). Model Implementasi Pendidikan Anti Korupsi Di Perguruan Tinggi Islam. Jurnal Kariman, 3(1), 1-6. https://doi.org/10.52185/kariman.v3i1.47

Arifuddin, A. (2019). Konsep Pendidikan Profetik (Melacak Visi Kenabian Dalam Pendidikan). Jurnal MUDARRISUNA: Media Kajian Pendidikan Agama Islam, 9(2), 319-338. http://dx.doi.org/10.22373/jm.vgi2.4782

Azwar S. (2006). Sikap Manusia: Teori dan Pengukurannya. Yogyakarta: Pustaka Pelajar

Budiningsih, C. A. (2004). Pembelajaran Moral: Berpijak pada Karakteristik Siswa dan Budayanya. Jakarta: Bhineka Cipta

C. Wade \& Tavris, C. (2007). Psikologi. Jakarta: Erlangga

Dananjaya, Utomo. (2010). Media Pembelajaran Aktif. Bandung: Nuansa

Doig, A., \& Riley, S. (1998). Corruption and anti-corruption strategies: Issues and case studies from developing countries. Corruption and Integrity Improvement Initiatives in Developing Countries, 45, 62.

Evans, Kevin. (2009). Sistem Pencegahan Korupsi Pada Upaya Penanggulangan Bencana Alam, Dalam Korupsi Mengorupsi Indonesia, Sebab, Akibat, dan Prospek Pemberantasan, Wijayanto, Ridwan Zachrie (Ed), Jakarta: Gramedia Pustaka Utama

Frimayanti, Ade Imelda. (2017). Pendidikan Anti Korupsi dalam Pendidikan Agama Islam, Jurnal AlTadzkiyyah: Jurnal Pendidikan Islam, 8(1). https://doi.org/10.24042/atjpi.v8i1.2098

Gaffar, A. (2016). Pendidikan Islam Berbasiskan Anti Korupsi. El-Furqania : Jurnal Ushuluddin Dan Ilmu-Ilmu Keislaman, 2(02), 196-208. Retrieved from http://ejournal.kopertais4.or.id/madura/index.php/elfurqania/article/view/2298

Gardiner, J. (2017). Defining corruption. In Political Corruption (pp. 25-40). Routledge.

Hadi, Kisno. (2010). Korupsi Birokrasi Pelayanan Publik di Era Otonomi Daerah. Jurnal Penelitian Politik LIPI. 7(1)

Hakim, L. (2012). Model integrasi pendidikan anti korupsi dalam kurikulum pendidikan islam. Ta'lim: Jurnal Pendidikan Agama Islam, 1O(2), 141-156.

Henderson, J. V., \& Kuncoro, A. (2011). Corruption and local democratization in Indonesia: The role of Islamic parties. Journal of Development Economics, 94(2), 164-180.

Intruksi Presiden Republik Indonesia No.1 Tahun 2013, tentang Aksi Pencegahan Dan Pemberantasan Korupsi Tahun 2013, Diundangkan Pada Tanggal 25 Januari 2013

Iqbal, Z. and Lewis, M.K. (2002). Governance and Corruption: Can Islamic Societies and the West Learn from Each Other. American Journal of Islamic Social Sciences, 19(2). Retrieved from https://www.researchgate.net/publication/228326715_Governance_and_Corruption_Can_ Islamic_Societies_and_the_West_Learn_from_Each_Other

J., Pope. (2003). Strategi Memberantas Korupsi. Jakarta: Yayasan Obor Indonesia

Kadir, Y. (2018). Kebijakan Pendidikan Anti Korupsi di Perguruan Tinggi. Gorontalo Law

Review, 1(1), 25-38. https://doi.org/10.32662/golrev.v1i1.95

Kartono, Kartini. (2013). Patologi Sosial. Jilid 1. Jakarta: RajaGrafindo Persada

Kementerian Pendidikan dan Kebudayaan RI Direktorat Jendral Pendidikan Tinggi. Pendidikan AntiKorupsi Untuk Perguruan Tinggi.

M. Fishbein \& Ajzein. I, Belief. (1975). Attitude, Intention and Behavior: An Introduction to Theory and Research. Sydney; Addison-Wesley Publishing

Montessori, M. (2012). Pendidikan antikorupsi sebagai pendidikan karakter di

Sekolah. Jurnal Demokrasi, 11(1), Article 1.

http://ejournal.unp.ac.id/index.php/jd/article/view/2561

Muhaimin. (2009). Rekonstruksi Pendidikan Islam. Jakarta. PT. Raja Grafindo Persada.

Mulyadi, Lilik. (2007). Tindak Pidana Korupsi di Indonesia, Normatif, Teoritis, Praktik dan Masalahnya. Bandung: PT Alumni 
Nugraheni, M. W. (2016). Pendidikan Antikorupsi Dalam Model Pembelajaran Bahasa Indonesia Terintegrasi Siswa Kelas VII Semester 1 SMP Negeri 1 Tembarak Tahun Ajaran 2010/2011. Transformatika, 12(1)

Nurdjana, Igm. (2010). Sistem Hukum Pidana dan Bahaya Laten Korupsi; Perspektif Tegaknya Keadilan Melawan Mafia Hukum. Yogyakarta: Pustaka Pelajar

Nur, R., Suardi, Nursalam, \& Kanji, H. (2021). Integrated Model of Character Education

Development Based on Moral Integrative to Prevent Character Value Breaches. AL

ISHLAH: Jurnal Pendidikan, 13(1), 107-116.https://doi.org/10.35445/alishlah.v13i1.272

Penkauskienè. (2006). Anti-Corruption Education at School: Methodical material for generaland higher education schools. Ministry of Education and Science of the Republic of Lithuania

Pradiptyo. Rinawan. (2009). Korupsi di Indonesia, Perspektif Ilmu Ekonomi. Dalam Korupsi Mengorupsi Indonesia, Sebab, Akibat, dan Prospek Pemberantasan. Wijayanto, Ridwan Zachrie (Ed). Jakarta: Gramedia Pustaka Utama

Samani, Muchlas. (2011). Konsep dan Model Pendidikan Karakter. Bandung: Remaja Rosdakarya

Semma, Mansyur. (2008). Negara dan Korupsi: Pemikiran Mochtar Lubis atas Negara, Manusia Indonesia, dan Perilaku Politik. Jakarta: Yayasan Obor Indonesia

Setiawan, N. K. (2012). Pribumisasi Al-Quran. Yogyakarta: Kaukaba

Supandi, Agus. (2015). Peran Pendidikan Anti Korupsi dalam Rangka Mewujudkan Pembangunan Nasional yang Bersih dari Korupsi. Research and Development Journal Of Education, 1(2)

Suparno, Herman. (2008). Pendidikan, Kemanusiaan, dan Peradaban dalam Landasan dan Arah Pendidikan Nasional Kita, Soedijarto. Kompas; Jakarta

Thoha, Miftah. (2012). Birokrasi Pemerintah dan Kekuasaan di Indonesia. Yogyakarta, Thafa Media Tim Penyusun Kamus Pusat Bahasa. (2008). Kamus Besar Bahasa Indonesia. Jakarta: Pusat Bahasa

Tim Penyusun. (2006). Memahami untuk Membasmi: Buku Saku untuk Memahami Tindak Pidana Korupsi. Jakarta: Komisi Pemberantasan Korupsi

Tim Penyusun. (2013). Panduan Penyelenggaraan Pendidikan Anti Korupsi di Madrasah. Jakarta: Kemenag RI

Undang-Undang Nomor 30 Tahun 2002 tentang Komisi Pemberantasan Tindak Pidana Korupsi.

Wibowo. Agus. (2013). Pendidikan Anti Korupsi di Sekolah. Yogyakarta: Pustaka Pelajar Wijayanto, et.al. (2010). Korupsi Mengorupsi Indonesia. Jakarta: Gramedia Pustaka Utama

Wijayanto. (2009). Memahami Korupsi. Dalam Korupsi Mengorupsi Indonesia, Sebab, Akibat, dan Prospek Pemberantasan, Wijayanto, Ridwan Zachrie (Ed). Jakarta: Gramedia Pustaka Utama Yaqin, Nurul. (2015). Program Pendidikan Anti Korupsi Di Madrasah. Jurnal Islamuna, 2(2) 